\title{
The Needs Analysis of Thematic Learning Model Based on Aneuk Jamee Culture Integrated with HOTS
}

\author{
Mardhatillah $^{1}$, Khairil Ansari $^{2}$, Abdurahman Adisaputera $^{2}$ \\ ${ }^{1}$ Primary Teacher Education, Universitas Negeri Medan, Indonesia \\ ${ }^{2}$ Universitas Negeri Medan, Indonesia \\ Email: mardhatillah.atjeh@gmail.com
}

\begin{abstract}
:
The aim of this research is to analyze the needs of the development of thematic learning model based on aneuk jamee culture integrated with HOTS. The study was conducted by survey method in 9 Elementary Schools in South Aceh Regency. The research subjects were 18 classroom teachers who taught thematic learning. The object studied was the principal's response to the development of a thematic learning model based on Aneuk Jamee tribe integrated with HOTS, the tendency of teachers to apply thematic models in school learning, student reasoning, and student character. Data collected by interview, questionnaire, observation, and test. Data were analyzed descriptively. The results of the analysis show that (1) principals have not yet fostered the development of thematic models, so they support development efforts, (2) teachers have not yet developed and used thematic models, so they support and express readiness to be involved in development, (3) learning models used by teachers so far there are no indications that lead to thematic models based on Aneuk Jamee integrated with HOTS.
\end{abstract}

\section{Keywords:}

thematic learning model; Aneuk Jamee; HOTS

\section{Introduction}

Education is the development of students' abilities so that education occurs because of the learning process. Learning is a mental activity so that behavioral changes occur that are very dependent on the acquisition of one's experience. Learning not only questions what students know, but also what students can do (content and performance) (Sinaga, 2008).

Formation of human character should begin early, especially in elementary schools (SD) as the most basic institutions that can be an initial milestone in the formation of student character. Formation of characters early on aims to make the character values that want to be built well recorded in the minds of students (Ariyani and Wangit, 2016).

Much of the learning that takes place in Aceh Province is traditional, especially in schools in rural areas such as some elementary schools in Singkil Regency, West Aceh, Seumelu and Nagan Raya. Facilities and infrastructure available are very minimal. In addition, learning activities have not utilized the culture and the environment as required in the 2013 Curriculum. Students who attend school on average come from lower middle families, teachers are not yet proficient in applying thematic learning, even though the 2013 thematic learning curriculum has long been applied in primary schools, and this is a problem that needs to be resolved (Mardhatillah, 2019).

Based on the initial study conducted, found several fundamental problems of learning in elementary schools in Aceh province, including: primary school learning in Aceh province still looks traditional, teachers still use ordinary textbooks as teaching materials, 


\section{Britain International of Humanities and Social Sciences (BIoHS) Journal \\ ISSN: 2685-3868(Online), 2685-1989(Print) \\ Vol. 2, No. 2, June 2020, Page: 490-494}

learning is more dominant using the lecture method, so students do not motivated in learning (Mardhatillah, 2017a).

A variety of literature that researchers found shows that: So far teachers use traditional learning more often than by applying thematic learning models, the material taught is textual so students memorize the material more (Saputro, 2015). The role of culture is very large in developing a nation's civilization, if traced there are many factors that influence social problems, including: education, cultural shifts, shifting national values, the ignorance of young people towards customs and so on (Nurdyansyah, 2015).

The application of learning models adopted from outside and adapted in schools requires students and teachers to change their teaching and learning behavior. Constructive interactions between students and their peers, students and teachers, student-teacher problems are very difficult to condition. Thematic learning is learning that uses themes as the subject of study and allows students both in groups and individuals to be active in exploring, searching and discovering scientific concepts holistically, meaningfully and authentically (Sa'dun Akbar, 2013). While according to Simorangkir (2019) Thematic learning is learning that is useful, interesting, meaningful, and appropriate for students in early primary school (SD) classes. The teacher must be creative in teaching, various approaches in learning need to be considered by the teacher so that learning can proceed in accordance with the objectives to be achieved.

Thematic and cultural learning of the Aneuk Jamee tribe is intended to make students more familiar with the values of wisdom that exist in the student's home environment. Specifically, thematic learning based on local wisdom Aneuk Jamee culture so that students are able to recognize, develop and preserve all the wealth and potential in the values of local wisdom in Aceh. Regional culture-based learning is able to create more meaningful learning so that it leads to improving student learning outcomes.

This research is the first step in efforts to develop a thematic learning model based on Aneuk Jamee tribe integrated with HOTS, namely by analyzing the needs of the learning model developed, this aims to obtain accurate information in the field about the extent to which this learning model is needed.

\section{Research Method}

This research uses research and development (R\&D) according to Plomp, which was adapted to the Dick \& Carrey development model as a grand design. This study focuses more on the needs assessment of the importance of developing aneuk jamee culture-based thematic learning models. Needs analysis is carried out through data exploration of the existence of the thematic learning model based on aneuk jamee culture integrated with HOTS, Learning Implementation Plan (RPP), Student Work Sheet (LKS), assessment of learning processes and products, perceptions and expectations of principals and teachers towards the development of learning models HOTS integrated aneuk jamee tribal culture based thematic.

The subjects of this study were elementary school students, elementary school teachers (The following are RPP products, worksheets, and assessments used), and the principal of elementary schools in South Aceh district. Sampling was determined by stratified random sampling technique. Teacher samples were taken from 18 of 9 schools. 
The object of this study is the thematic learning model and its tools that are available and used by teachers in South Aceh district. The instruments used to collect data, are interview guides for school principals, questionnaires for teachers, guidelines for observing learning models used so far, tests for student reasoning, and HOTS questionnaires. To analyze research data, descriptive analysis techniques are used.

\section{Discussion}

Based on the results of interviews with school principals, it can be described that school principals tend not to have done any coaching specifically in developing studentcentered learning models. The lack of guidance done by the school principal is due to the school principal's understanding of learning models that are inadequate.

Therefore, $100 \%$ of school principals stated that they highly expect research efforts to develop aneuk jamee culture-based thematic learning models and 100\% of school principals said they would provide opportunities and support for teachers to take part in training programs to develop thematic learning models based on the Aneuk Jamee ethnic culture. The results of teacher response data analysis show that the learning models that are diverly applied by the teachers in learning are less empowering the learners' self potential. The learning models are (1) assignment model, (2) classical lecture model, (3) question and answer discourse model, (4) homework assignment model, (5) teacher demonstration model, (6) model student assignments for experiments based on the teacher's example, and (7) computer simulation models demonstrated by the teacher.

In addition to cooperative learning, there are also a small number of teachers who have applied traditional methods while thematic learning has not been implemented optimally. The reason teachers do not use thematic learning models in learning, because they do not understand much of these models. Therefore, teachers who stated that they really need and expect efforts to develop thematic models based on the culture of aneuk jamee tribe integrated with HOTS, they consider it very necessary efforts are made, they support the development efforts and they will prepare themselves to be involved in the development process and product learning model implementation.

Cultural recognition of children from an early age has a dual role, (Isnanda 2018) explained, namely as an introduction to wisdom, and as forming the child's character. Children from an early age are reasonable to be introduced to the local culture to recognize their environment, rather than being allowed to freely study foreign cultures which is not yet time for them to see, so the impact is on the deterioration of character in children. Through the introduction of local culture, students can love their villages, culture and environment.

One's academic intelligence contributes to success by $20 \%$, while the biggest determinant of success by $80 \%$ is derived from attitude. This shows how important the attitude of character that must be possessed by someone, and a positive attitude like this is what is embodied in the local culture of the nation that we can explore and implement in the learning process that starts from basic education.

For this reason, stakeholders are expected to be able to make efforts to transform the cultural values of the Aneuk Jamee tribe to millennials, through education, outreach and so forth so that the millennial generation in South Aceh Regency is a regency inhabited by the majority of the Aneuk Jamee tribe has a good local cultural character so it is expected to become millennial with local character and global outlook. 
The aneuk jamee culture-based thematic learning model is expected to improve students' higher-order thinking skills, and can facilitate teachers in creating effective and efficient learning.

\section{Conclusion}

Based on the results of research and discussion presented previously, it can be concluded as follows. (1) The school principals responded that it was very important to develop the thematic learning model based on aneuk jamee culture integrated with HOTS. (2) The school principal has not provided coaching specifically to teachers in developing thematic models based on Aneuk Jamee culture integrated with HOTS. (3) Thematic learning model based on aneuk jamee culture integrated with HOTS has not been found in the praxis of education. (4) The teachers do not have sufficient experience in implementing thematic learning based on the aneuk jamee tribe integrated with HOTS. Learning and learning assessment carried out so far is more product oriented rather than process.

This research has revealed that there have been no efforts of teachers, principals, and schools to develop thematic learning models based on Aneuk Jamee ethnic culture. The model of its existence has never been used by teachers in learning. Therefore, the following suggestions are proposed in order to be able to use thematic learning models based on culture and in accordance with the daily context of students, so that learning in the classroom can be more effective and efficient.

\section{References}

Akbar, S. (2013). Instrumen Perangkat Pembelajaran. Rosdakarya.

Anzar, S. F., \& Mardhatillah, M. (2018). Analisis Kesulitan Belajar Siswa Pada Pembelajaran Bahasa Indonesia di Kelas V SD Negeri 20 Meulaboh Kabupaten Aceh Barat Tahun Ajaran 2015/2016. Bina Gogik: Jurnal Ilmiah Pendidikan Guru Sekolah Dasar, 4(1).

Ariyani, Y. D., \& Wangit, M. N. (2016). Pengembangan Bahan Ajar Tematik-Integratif Berbasis Nilai Karakter Peduli Lingkungan Dan Tanggung Jawab. Jurnal Pendidikan Karakter, 6(1), 116-129.

Mardhatillah. (2017). Peningkatan Pengetahuan Guru Sd Dalam Mendesain Media Pembelajaran. Seminar Nasional FIS Berwawasan Kebangsaan, 1(1), 457-461.

Mardhatillah, Verawati, Eviyanti, E., \& Pramuniati, I. (2019). BAHAN AJAR INTERAKTIF BERBASIS KEARIFAN LOKAL. Genta Mulia, X(1), 38-53.

Mardhatillah, M., Verawati, V., Evianti, E., \& Pramuniati, I. (2019). Bahan Ajar Interaktif Berbasis Kearifan Lokal Melalui Pendekatan Saintifik pada Pembelajaran Bahasa Inggris. Genta Mulia: Jurnal Ilmiah Pendidikan, 10(1).

Mardhatillah, M., \& Trisdania, E. (2018). Pengembangan Media Pembelajaran Berbasis Macromedia Flash Untuk Meningkatkan Kemampuan Membaca Siswa di SD Kelas II Negeri Paya Peunaga Kecamatan Meureubo. Bina Gogik: Jurnal Ilmiah Pendidikan Guru Sekolah Dasar, 5(1).

Nurdyansyah. (2015). Model Social Reconstruction Sebagai Pendidikan Anti-Korupsi Pada Pelajaran Tematik di Madrasah Ibtida'iyah Muhammadiyah 1 Pare Nurdyansyah. HALAQA: Jurnal Pendidikan Dan Keislaman, 14(1), 13-23. http://eprints.umsida.ac.id/id/eprint/1620

Saputro, H. B. (2015). Pengembangan Media Komik Berbasis Pendidikan Karakter Pada Pembelajaran Tematik-Integratif Kelas IV SD. Jurnal Prima Edukasia, 3(3), 61-72. 
Sinaga, B. (2008). Paradigma Lama Kontra Paradigma Baru Pembelajaran Di Sekolah. Generasi Kampus, 1(2), 1-13.

Simorangkir, F.M.A and Tanjung, D.S. (2019). Implementation of Multiple Intelligences Approach Based On Batak Angkola Culture in Learning Thematic For Class IV SD Negeri 100620 Pargarutan Julu South Tapanuli District. Budapest International Research and Critics in Linguistics and Education (BirLE) Journal, 2(4); 547-551. 